\title{
Gode erfaringer med kognitiv miljøterapi
}

\author{
Kognitiv miljøterapi åpner for bedre samarbeid med pasienten.
}

\begin{abstract}
denne artikkelen vil vi beskrive våre erfaringer med kognitiv miljøterapi i to sengeposter på Psykiatrisk klinikk ved Sykehuset Levanger; Seksjon psykoser og Seksjon allmennpsykiatri. Seksjonene tilbyr behandling av pasienter med til dels svært forskjellige behov, og vi har siden 2007 og 2009 valgt en kognitiv tilnærming i miljøterapien. Kognitiv miljøterapi krever et godt samarbeid, både mellom pasientansvarlig behandler, miljøkontakt og de ulike faggruppene. Pasienten står i sentrum, deltar aktivt i egen behandling og lærer mestringsmetoder som kan brukes hjemme. Pasienten lærer om sin egen sykdom og får kunnskap om forebygging av nye sykdomsepisoder. Vi mener kognitiv terapi går godt sammen med vårt ergoterapifaglige og sykepleiefaglige tenkningsgrunnlag.
\end{abstract}

\section{Bakgrunn}

Psykiatrisk avdeling har 16 sengeplasser ved Seksjon allmennpsykiatri og ti plasser ved Seksjon psykoser. I begge seksjoner samarbeider miljøterapeuter og pasientansvarlige

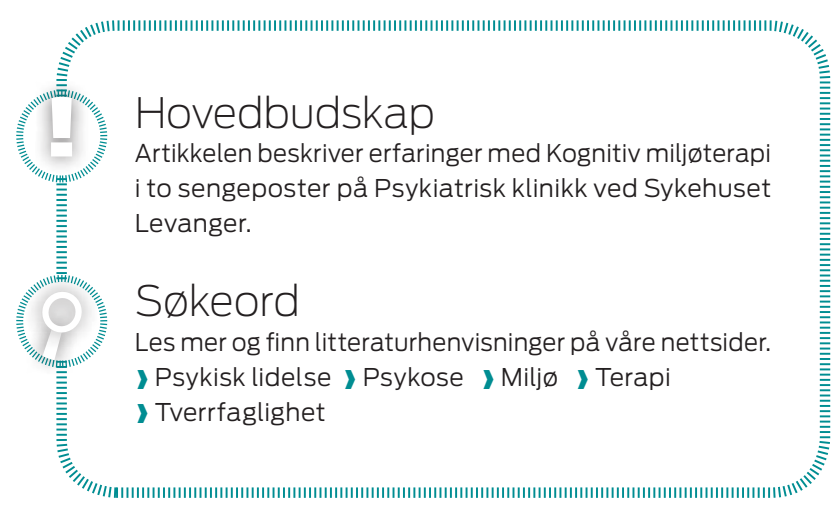

behandlere tett for å kunne gjennomføre kognitiv miljøterapi og skape et godt terapeutisk miljø. I tillegg har vi et aktivt samarbeid med pasienten for å oppnå best mulig resultat. Felles mål og tiltak for behandling er definert i behandlingsplan i pasientens journal. Pasienten får en kopi av behandlingsplanen.

Moderne miljøterapi kan betraktes som samspill på grunnlag av medmenneskelighet og respekt. Miljøterapi bygger på den grunnleggende antakelsen om at hele institusjonen, frisk luft, meningsfulle aktiviteter, fysisk aktivitet, psykoterapi og så videre, ikke bare medisin, påvirker pasientens holdninger og atferd. Et annet fellestrekk for alle former for miljøterapi er at de bygger på humanistiske idealer og en oppfatning av at mennesker lever i relasjoner, ikke som «isolerte øyer». (1)

Kognitiv terapi (KT) vektlegger særlig måten vi tenker og handler på, og hvordan dette kan påvirke følelser og utløse kroppslige reaksjoner hos oss. KT fokuserer på å styrke pasientens egne ressurser, lette problemer og gi symptomreduksjon. Hypotesen er at atferd og følelser påvirkes av hvordan vi oppfatter og tolker hendelser. Det er ikke en spesiell situasjon som bestemmer hva vi tenker, gjør eller kjenner, men måten vi konstruerer situasjonen på. Sentrale begrep i KT er tidligere erfaringer, negative grunnleggende leveregler, negative automatiske tanker, ubehagelige følelser, utløsende situasjoner og atferd.

\section{Negative leveregler}

Mobbing, dårlig mestringsevne eller mye kritikk i oppveksten kan ha dannet negative grunnleggende leveregler hos oss. Eksempel på slike leveregler er: jeg er ikke god nok, jeg er annerledes. Før eller siden i livet kan vi havne i utfordrende situasjoner. Vi kan risikere å miste jobben, gjennomgå en skilsmisse eller miste personer som står oss nær. I slike situasjoner kan de negative grunnleggende levereglene tre tydeligere frem og medvirke til negative automatiske tanker. Disse tankene utløser ubehagelige følelser hos oss, og kan bidra til å låse eller forsterke en uheldig situasjon eller atferd.

Holm m.fl. definerer kognitiv miljøterapi som «en aktiv, struktureret, problemorienteret, psykoedukationel og dynamisk behandlingsform. Den kognitive behandlingsmodel i miljøet giver patienten mulighet for at finde alternativer til uhænsiktsmæssige reaktionsmønstre og utvikle nye færdigheder.» (2, s. 17).

KT har tradisjonelt vært en individuell behandlingsform man har benyttet i samtalerommet mellom terapeut og pasient, mens i kognitiv miljøterapi (KMT) har man tatt grunnleggende elementer fra KT og benyttet i miljøterapien. Det betyr at KMT i større grad gjør det mulig å utnytte "gylne øyeblikk» i hverdagen. Mange pasienter synes det kan være vanskelig å hente opp erfaringer de gjør seg i hverdagen i samtaler med sin behandler. I KMT er den kognitive terapeuten aldri langt unna, og situasjoner som oppstår kan utnyttes der og da. Man kan kartlegge reaksjoner og utnytte hverdagssituasjoner til å øve på individuelle kognitive problemstillinger.

Pasient: «Jeg var ute og gikk tur da jeg plutselig merket at hjertet slo kraftig. Jeg trodde jeg skulle dø. Fysioterapeuten som gikk sammen med meg spurte om jeg hadde drevet med idrett tidligere, og om jeg husket hvordan hjertet reagerte da. Da kom jeg på at pulsen naturligvis slår hardere når jeg er 


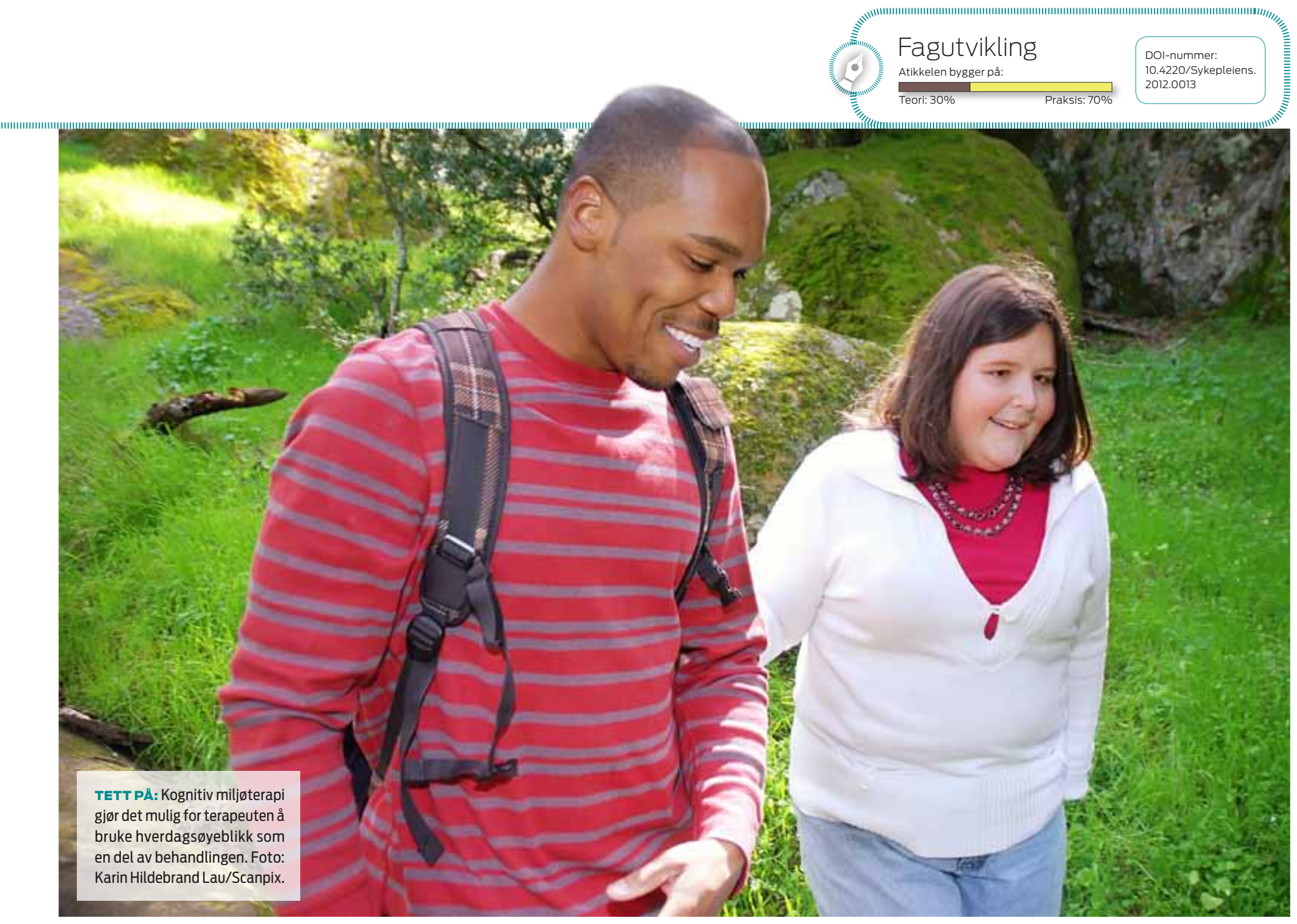

i aktivitet. Jeg tenkte meg om og skjønte at pulsen hadde økt fordi vi nettopp hadde gått opp en bakke. Dessuten vet jeg jo at jeg er i dårlig fysisk form. Denne oppdagelsen gjorde at redselen slapp».

\section{Likheter}

KMT gir, slik vi ser det, en ramme og et språk til samarbeidet med pasienten uavhengig av diagnose og spesifikke problemområder. Pasienter med ulike diagnoser, for eksempel angst, depresjoner og psykoser, har nytte av å jobbe strukturert med kognitiv tilnærming. Uansett diagnose fokuserer KT og KMT på pasientens tankermønster og tolkninger. Utfordringen er å tilpasse den kognitive tilnærmingen til individuelle behov.

I begge seksjoner har vi samme forståelse av den kognitive terapeutens rolle i miljøterapien. Terapeuten skal delta aktivt i samtalen. Dette innebærer å informere, forklare, gi råd og stille konkrete spørsmål til pasienten. Terapeuten skal være klar, tydelig og enkel å forholde seg til. Behandlingsalliansen er sentral i kognitiv terapi, og pasienten må være engasjert og aktivt delta i behandlingen hvis man skal oppnå resultater. I tillegg må målet vi skal arbeide mot være tydelig og klart definert. Vi støtter pasienten i å mestre problemer og utfordringer. Han trenger hjelp til å forandre på uhensiktsmessige handlinger og tankemønstre, som både kan være resultat av og årsak til problemer. Terapeuten skal observere uten å tolke, men forsøke å forklare hva som skjer og hvorfor, slik at terapien blir forståelig for pasienten. Vi ønsker at pasienten blir en aktiv problemløser og medarbeider i behandlingen. Dette underbygges av Holm og gruppe. Disse aktivitetene inngår i en fast ukeplan som også omfatter døgnstruktur og måltid. Planen gir forutsigbarhet og regelmessighet. Til tross for at seksjonene har ulikt innhold og struktur, er hensikten den samme. Alle faste aktiviteter skaper en arena for å arbeide med konkrete individuelle utfordringer.

Pasient: «Jeg har ligget mye til sengs i det siste på grunn av angst, triste følelser og mangel på overskudd. Under innleggelsen ble vi

\section{«Jeg ble overrasket over hvor positivt en enkel ting som mat og en normal døgnrytme virket inn på hverdagen min.»»}

medforfattere: «Dette innebærer, at terapeuten sammen med patienten ud fra automatiske tanker i den konkrete situation formulerer hypoteser om de underliggende antakelser, der fastholder patienten i bestemte handlemønstre» (2, s. 165).

\section{Faste aktiviteter}

Både i Seksjon psykoser og Seksjon allmennpsykiatri har vi blant annet psykoedukative grupper, fysisk aktivitetsgruppe og frilufts- enige om å prøve å normalisere døgnrytme og måltid, og arbeide med kognitive teknikker jeg har lært tidligere. Jeg skulle trene på å stå opp til frokost, spise og drikke litt til alle måltid og delta i postens program. Dette fikk jeg til ganske bra etter hvert, med støtte fra personalet. Senere laget vi en oversikt over konsekvensene på tavla, og jeg ble overrasket over hvor positivt en enkel ting som mat og en normal døgnrytme virket inn på hverdagen min. Nå har jeg mye mer overskudd til å gjøre 
litt husarbeid, være sammen med familien min og besøke venner. Dermed får jeg trent på å omgås andre, gå i butikker og så videre. Angst, nedstemthet og skyldfølelse plager meg mindre nå».

\section{Undervisning}

I begge seksjonene har vi undervisning eller psykoedukative grupper som et fast innslag på ukeplanen. Dette finner vi belegg for i litteraturen (2). Hensikten er å formidle kunnskap om psykiske lidelser og grunnprinsipper i KT. Vi foreslår nye og hensiktsmessige løsningsstrategier, og lar pasientene dele erfaringer og lære av hverandre. Fokus er å utforske alternative løsninger som kan bidra til hensiktsmessige endringer hos den enkelte pasient. De samme erfarne miljøterapeutene har undervisning fra gang til gang. Vi avslutter alltid undervisningsdagene med en hjemmeoppgave til neste gang, slik at pasientene kan trene daglig på de kognitive prinsippene de har lært. Disse fellesnevnerne skal bidra til å øke effekten av undervisningen ved å stimulere til at pasientene deltar og engasjerer seg mer. Grunnlaget for undervisningen er det samme ved begge seksjonene, men de blir gjennomført forskjellig ut fra pasientenes spesifikke behov. Slik oppnår vi best mulig

\section{«Den kognitive modellen har hjulpet meg til å tenke annerledes.»}

effekt av psykoedukasjonsgruppene. Vi ønsker at personalet skal møte pasientene med en kognitiv tilnærming i ulike situasjoner til alle døgnets tider. Miljøpersonalet skal ikke nødvendigvis ha svar på pasientens spørsmål eller finne løsning på alle problemer, men hjelpe pasienten til selv å finne fram til svaret.

\begin{abstract}
Ulikheter
Seksjonene baserer sin KMT på de samme teoretiske rammene. Liggetiden ved Seksjon allmennpsykiatri er kort, bare 14-21 dager. Seksjon psykoser har en gjennomsnittlig liggetid på omtrent 50 dager. Problematikken er ulik, fra lettere psykiske lidelser til mer alvorlige. Skal vi oppnå hensiktsmessig behandling for de forskjellige gruppene, krever det ulik tilnærming. Sentrale faktorer som styrer utfor-
\end{abstract}

mingen av KMT er symptomtrykk og kognitiv funksjon.

\section{Tvangsbehandling}

Mennesker med alvorlige psykiske lidelser kan ha redusert innsikt i egen sykdom. En varierende andel av pasientene ved Seksjon psykoser er under tvangsbehandling. Vi erfarer at KMT også fungerer når pasienten ikke mottar behandling frivillig. Ofte er de symptomrelaterte temaene, som vrangforestillinger, sensitive i en akuttfase. I en startfase kan slike temaer ofte bli for utfordrende å jobbe kognitivt med. Pasient og terapeut kan likevel bli enige om andre samarbeidstemaer, som ikke berører pasientens motstand og innsikt. Arbeid med kognitive metoder rundt tema pasienten selv har valgt, bør være første del av engasjementsog sosialiseringsfasen i kognitiv terapi. I denne fasen gir vi pasientene en mulighet til å oppdage den positive effekten en kognitiv tilnærming kan ha. I Seksjon allmennpsykiatri kan vi oppnå engasjement hos pasienten i løpet av få undervisningstimer. Seksjon psykoser opplever imidlertid at det er hensiktsmessig å bruke lengre tid, både i undervisningsrommet og i hverdagssituasjoner, for at mennesker med alvorlige psykiske lidelser skal bli engasjerte i og se nytteverdien av denne metoden.

\section{Undervisning}

Seksjon allmennpsykiatri har to psykoedukative grupper hver uke, hver på $45+30$ minutter, med 15 minutters pause. Gruppene er lagt opp som kurs i kognitiv terapi med gruppeterapeutisk tilnærming. Eksempler på tema er angst, depresjon, fysisk aktivitet og søvnproblematikk. De to første undervisningsdagene omfatter en enkel opplæring i kognitiv teori, ulike teknikker og hjelpemidler. Videre underviser vi om kognitive modeller for angst og depresjon, i tillegg til metoder for mestring av symptomer

Seksjon psykoser har valgt å avgrense undervisningen til en dag i uka med en varighet på 30 minutter. Dette er av hensyn til pasientgruppens symptomtrykk og kognitive funksjon. Av samme grunn er innholdet i undervisningen begrenset. Vi vektlegger visualisering og refleksjon i undervisningen for å skape engasjement og deltakelse i pasientgruppen. Temaene er grunnleggende kognitiv terapi, kognitive verktøy og motivasjon for endring. Dette blir fordelt på fem sesjoner.

Pasient: «Det var tøft å møte i gruppa, og veldig tøft å fortelle om problemene mine. De forferdelige stemmene var en svært privat ting å snakke om. Når jeg først fortalte om dette og fikk høre at en til i gruppa hadde nesten lignende stemmer ble jeg overrasket. Jeg trodde ikke at andre hadde det slik. Det ble lettere å snakke om det samtidig som den andre hadde kloke tanker om sitt lignende problem. Temaet denne dagen var ABC-modellen der vi skulle beskrive en vanskelig situasjon. Det ble til at vi diskuterte min situasjon, og det var veldig nyttig».

\section{Veiledning}

Vi vurderer sammensetningen av pasientgruppen. I Seksjon psykoser vurderer behandlingsteamet om pasienten skal få tilbud om å delta eller ikke. Vi ser at gruppen ikke bør være for stor, da det kan giøre situasjonen uoversiktlig. I Seksjon allmennpsykiatri erfarer vi at pasientene tåler større grupper bedre, og alle pasientene som har mulighet deltar. Utfordringen blir i stedet å sørge for at alle deltakerne får komme med innspill.

Hjemmeoppgaver er sentralt i begge seksjoner, men pasientenes behov for oppfølging varierer. Som hovedregel kan man si at mennesker med lette psykiske lidelser er stand til å jobbe mer selvstendig med hjemmeoppgavene enn de med alvorlige lidelser. Seksjon psykoser møter denne utfordringen ved å gi ekstra støtte til gjennomføring av hjemmeoppgaver. Det blir gjort ved å sette av fast tid til dette i pasientens ukeplan. Vi ser at effekten av undervisningen $ø$ ker når vi bruker nok ressurser på veiledning og støtte til å gjennomføre hjemmeoppgavene.

\section{Erfaringer}

Skal man lykkes med å omstrukturere miljøterapeutisk retning i en sengepost, er det avgjørende med forankring i ledelsen. Man må avgjøre hva enheten ønsker å oppnå. Videre må man legge til rette for kunnskapsøkning i personalgruppa. Vi har erfart nytten av ildsjeler som brenner for temaet, og som motiverer og veileder i hverdagens utfordringer.

I implementeringsfasen er påfyll av kunnskap i alle ledd av organisasjonen avgjørende. Begge seksjoner har prioritert å gi Norsk Forening for Kognitiv Terapi sitt innføringskurs til mange medarbeidere. Tidligere erfaringer har vist at det kan oppstå behov for kunnskap utover innføringskurset på spesifikke tema, for eksempel KT ved psykose. Vi mener dette handler både om en kognitiv forståelse av psy- 
kotiske symptomer og en annen innfallsvinkel til den kognitive miljøterapien. Seksjon psykoser har sett at medarbeidere med gjennomført påbyggende kurs i psykoseproblematikk kom lettere i gang med kognitiv terapi enn de som bare hadde innføringskurs.

Blant faktorer som har hatt stor betydning for implementering av KMT mener vi psykoedukasjonsgruppene har vært viktige. Gruppenes betydning som implementeringsverktøy kan beskrives ut ifra forskjellige erfaringer. Vi ser en tendens til at de som er kursledere også jobber mer kognitivt rettet med pasienten i det daglige. De får en motivasjons- og veilederrolle i forhold til de blant personalet som er mer usikre i bruk av kognitive verktøy. Seksjon allmennpsykiatri praktiserer at to til tre ansatte til enhver tid kan være observatører i de psykoedukative gruppene. Dermed brukes gruppene også til opplæring av ansatte, både fra egen og andre seksjoner. Summen av dette er at personalet i avdelingen får en økt kollektiv bevissthet om det å jobbe ut fra prinsippene i KMT. Vi mener også at fordeling av undervisningsansvar for de kognitive gruppene på flere medarbeidere er hensiktsmessig. Det gjør avdelingen mindre sårbar enn om ansvaret legges på svært få personer.

Gjennom denne prosessen har vi oppdaget flere ting, blant annet at det å «jobbe kognitivt» ikke innebærer store omveltninger i forhold til hvordan vi har arbeidet tidligere. KMT er også en eklektisk modell, som setter elementer fra flere metoder inn i en helhetlig ramme. Dette øker motivasjonen for å fortsette. Utfordringen blir i hovedsak å bruke velkjent kunnskap i en ny sammenheng. Vi ser særlig tre viktige endringer som følge av implementeringen av KMT:

1. Pasientperspektivet. Vi ser tydelig at KMT $ø$ ker pasientens mulighet for selvstendighet og delaktighet i behandlingen. Pasientens opplevelse av egen situasjon er utgangspunktet for behandlingen. Et godt resultat er avhengig av at pasienten deltar og alle tiltak som skal medføre endring krever samarbeid.

Pasient: «Før har jeg hatt en del innleggelser på sykehus og prøvd forskjellige metoder mot depresjon og angst med lite hell, får man si. Det har gått ut på samtaleterapi, gruppeterapi, arbeidsstue og fysisk aktivitet. Nå har jeg begynt å få tak på tanker og følelser og fått satt det i et system på et vis. Dette har hjulpet meg gjennom sykdomsperioder».
2. Endringsperspektivet står sterkt i KMT. Alle intervensjoner rettes mot at pasientene kan foreta avgjørende endringer i sin være- og tenkemåte, noe som øker evnen til å håndtere utfordringene de har.

Pasient: «Den kognitive modellen er det som har hjulpet meg til å tenke annerledes og vært nøkkelen for meg. Når jeg har løst et problem, så oppdager jeg også løsningen på mange andre små dagligdagse problemer som betyr så mye for meg i hverdagen. Før var jeg jævlig ensporet, hektet meg opp i den første tanken jeg fikk. Uten «nøkkelen〉 fant jeg ingen alternativ. Nå finner jeg straks en alternativ løsning.

3. Dempe ubehag. Der man tidligere hadde som mål å fjerne symptomer og plager, tenker vi nå pasienten kan dempe og håndtere ubehag på en mer hensiktsmessig måte av pasienten selv. Til det behøver man ulike mestringsstrategier og alternative tenkemåter som man må trene på.

Pasient: «Målsetting er viktig for meg. Jeg må huske på å lage meg små, konkrete delmål. Målene må ikke være for ambisiøse! Det har jeg brent meg på mange ganger. En ting kan være et mål om å kjøpe blomster til leiligheten. Da må jeg vanne og stelle blomstene, så blir det trivelig å være der. Jeg kjøpte en godstol også, så jeg kunne se på TV. Dermed kunne jeg prate med folk om det som gikk på TV. Det ble trivelig å være sammen med folk og naturlig å rydde og vaske i leiligheten til helga. Mange små delmål og gjøremål har til sammen skapt trivsel der jeg bor».

\section{Felles språk}

Disse tre faktorene betyr at vi som terapeuter må gi fra oss en del kontroll i behandlingsprosessen. Det er svært givende for oss å se at pasienten deltar mer i behandlingen. Ofte handler den innledende fasen $\mathrm{i}$ behandlingen om at pasient og terapeut må avklare sine perspektiver på pasientens situasjon. Man må også diskutere tanker om hva som kan være riktig behandling. Til slutt må pasient og behandlere bli enige om en felles målsetting. KMT gir oss en felles plattform som lar pasientene beskrive sin situasjon i et språk som personalet forstår. Et felles språk gjør samarbeidet lettere. Alliansen styrkes når pasient og behandler opplever å forstå problemet på samme måte. Psykoedukasjonsgruppene gir oss verktøy som pasient og terapeuter kan benytte i fellesskap.
KMT legger til rette for at pasient og terapeut har et felles prosjekt å samarbeide om, nemlig $ø$ kt livskvalitet og bedre symptommestring for pasienten.

Pasient: «Hvis jeg lykkes med kognitiv terapitenkning slik jeg har lært, så holder jeg meg stabil og finner lettere løsninger på problemer. Da tar jeg også medisinen min og holder avtaler, for eksempel med ansvarsgruppa i kommunen. Det er med på å holde meg stabil, og da greier jeg å fortsette med kognitiv terapitenkning. Problemet oppstår hvis jeg får sykdomsperioder og faller ut av den gode sirkelen min. Da vet jeg at jeg snarest mulig må få hjelp til å komme meg inn dit igjen».

\section{Veien videre}

Våre erfaringer med KT og KMT er positive. Samtidig ser vi utfordringer og forbedringspotensial. Kravet til individualisert tilnærming krever mer ressurser fra personalet enn det en fast undervisningspakke gjør. Det betyr at vi må være gode til å fange opp de som trenger ekstra oppfølging. Dette gjelder ofte i engasjerings- og sosialiseringsfasen, men også overfor pasienter som har et for stort symptomtrykk. De kan likevel delta i gruppene for fellesskapets del, og få tilbud om et nytt opphold senere når de fungerer bedre kognitivt og kan konsentrere seg om innholdet i undervisningen. Vi har oppdaget at en god kognitiv utredning er nyttig med tanke på å kartlegge pasientenes forutsetninger for å kunne ta i bruk KT. Herunder kommer vurdering av pasientens evne til sykdomsinnsikt. Mange av våre pasienter har oppfølging fra hjemkommunene utenom innleggelsene. Noen trenger videre veiledning i det kognitive arbeidet de har begynt på under innleggelsen. Vi ser en mulighet til forbedring i at flere i det kommunale hjelpeapparatet får kjennskap til KT. De som allerede har innføringskurset, men som ikke bruker det, bør få støtte til å komme i gang. Dermed vil pasienten kunne sikres kontinuitet og forutsigbarhet i arbeidet med å nå sine målsettinger, både i sin hjemkommune og under innleggelser i sykehus. IIII

\section{LITTERATUR}

1. Thorgaard L, Haga E. Relationsbehandling i psykiatrien, bind 1. Gode relationsbehandlere og god miljøterapi. Stavanger: Hertevig Forlag. Stavanger/Psykinfo Forlaget Risskov, 2006.

2. Holm L, Oestrich IH, Austin S, Beck S, LaCour LL, Lykke J. Kognitiv miljø terapi. At skabe et behandlingsmiljø i ligeverdigt samarbejde. Virum: Dansk psykologisk forlag As, 2006 